Peshawar Journal of Psychology and Behavioral Sciences, 2015, Vol. 1, No. 2, 137-150

\title{
Corporal Punishment: Parents Perception in District Malakand, Khyber Pakhtunkhwa, Pakistan
}

\author{
Nayab Ali ${ }^{1}$, Mussawar Shah' ${ }^{2}$ Intikhab Alam ${ }^{3}$ and \\ Shakeel Ahmad ${ }^{4}$ \\ The University of Agriculture, Peshawar, Pakistan
}

This paper shed light on parent's psychological perception about children corporal punishment in District Malakand, Khyber Pakhtunkhwa, Pakistan. A total of 202 respondents (parents) were selected through simple random sampling procedure to portray information. Chi square $\chi 2$ and Gamma statistics were used to determine the level of association and strength and direction of relationship. Majority of the respondents i.e. $82.7 \%$ had opined that corporal punishment increases aggressiveness in children, it promotes depression $(82.2 \%)$, fear and terror 153(75.7), eliminate confidence and damage IQ of children 146 (72.3). Moreover, at bivariate level a positive $(\gamma=.977)$ with significant relationship $(\mathrm{P}<0.05)$ was discovered between corporal punishment increases aggressiveness with corporal punishment. A positive $(\gamma=.972)$ with significant relationship $(\mathrm{P}<0.05)$ was discovered between corporal punishment promotes depression with corporal punishment. Similarly, A positive $(\gamma=.954)$ with significant relationship $(\mathrm{P}<0.05)$ was discovered between corporal punishment stimulate nervousness with corporal punishment. A positive $(\gamma=.944)$ with significant relationship $(\mathrm{P}<0.05)$ was discovered between corporal punishment leads to fear and terror with corporal punishment. A positive $(\gamma=.914)$ with significant relationship $(\mathrm{P}<0.05)$ was discovered between corporal punishment eliminate confidence with corporal punishment. A positive $(\gamma=.913)$ with significant relationship $(\mathrm{P}<0.05)$ was discovered between corporal punishment damage IQ of children with corporal punishment. A

${ }^{1}$ M.Phil Scholar, Department of Rural Sociology, The University of Agriculture Peshawar, Pakistan

${ }^{2}$ Professor and Chairman Department of Rural Sociology, The University of Agriculture Peshawar, Pakistan

${ }^{3}$ Lecturer, Department of Rural Sociology, KP The University of Agriculture Peshawar, Pakistan

${ }^{4}$ M.Phil Scholar, Department of Rural Sociology, The University of Agriculture Peshawar, Pakistan 
positive $(\gamma=.915)$ with significant relationship $(\mathrm{P}<0.05)$ was discovered between corporal punishment decline feelings of sympathy with corporal punishment. It is concluded from the study findings that corporal punishment results in emotional distress, lack of confidence, increase aggressiveness, fear and terror, depression, damage IQ of children etc. Regular periodic refreshers courses need to be arranged by the education department to emphasize the worse effects of corporal punishment and certain psychological assessment tests of children at school by medical officers to mitigate the social and psychological distress, as resulted from use of corporal punishment.

Keywords. Corporal punishment, parents parent's perception, measurement and Pakistan.

Lambert (2010) pointed out that the term corporal punishment is originated from a Latin word, which is meant "body". The word corporal punishment may be stated as "Hurt given to someone consciously in order to end or modify bad actions" (Hyman \& Perone, 1998). It can also be defined as infliction of bodily pain deliberately for the purpose of altering misbehavior. There are various methods used for it like beating, pushing by hand, kick by foot, pinching, corporal punishment is applied by using of a variety of substance such as sticks made of wood, belts, brushwood, giving electric shock, shaking, by extreme exercise, not allowing to go for urine and removal of chairs etc (Bauer et al., 1990). Corporal punishment is a consciously execution of force to causes hurt for giving penalty to someone. Different methods are used for the application of physical punishment like children are beat by hands, hit by wooden stick, belt, kicking by foot, slapping, flaming, pulling hair, not allowed someone to go to latrine, stand in heat compel students to clean their mouths with soap or forcing them and forced someone on unnecessary exercise" (Salim, 2005). According to Eggleton "The process of giving instruction to someone to correct his/her intellectual faculty, also it carries out the purpose to taught conformity to power or rules, retribution to correct bad habits. On the other hand, obedience does not essentially obtain by giving physical punishment. People consider corporal Punishment as a vital tool to restore obedience but it is 
challenging and has a lot of bad impacts for all parts of schooling i.e. teachers, students and administrators" (Eggleton, 2001). According to Committee on the Rights of the Child corporal punishment may be defined as "the intentional infliction of power to produce harm" (CRC, 2006). The word physical punishment can also be defined as "the use of physical force with the objective to cause pain, not wound, for the reason of improvement or to organize child activities" (Straus, 2009). Gershoff and Bitensky (2007) argued that "the application of force in order to produce pain for the purpose of discipline the child's actions is called corporal punishment".

\section{Objectives}

1. To study the parents perceptions regarding corporal punishments in the sampled area

2. To see association between independent variable psychological effects with dependent variable corporal punishment

3. To make policy recommendations on the basis of study findings

\section{Method}

Area selected for this study was Union Council Bandajat of Town Thana, District Malakand. This area was selected purposively as number of educational institutions in this area is greater than other regions of the District; also this area is most literate region throughout the whole District Malakand. Literacy rate of the area is $42 \%$ according to population census report 1998. The study area comprise of 800 families (District Census Report, 1998).

The population was further divided into literate and illiterate to make strata. As it was cleared by the population census report that literacy ratio of the area is $42 \%$ and illiteracy ratio is $58 \%$, so the number of literate household heads in the study area was 336 and illiterate was 464 respectively. As it was point out that for 800 population the sample size would be 202 (www.wessa.net/rwasp_sample.wasp). So 202, family heads were selected through simple random sample methods/procedure. So on the basis of proportionate sample distribution the sample size for literate persons was 85 and 117 for illiterate respectively.

Data was collected through well structured/scale interview schedule. The collected data was analyzed by using uni-variate and bi- 
variate analysis respectively. At uni-variate level percentages and frequencies were used to know about the phenomena of corporal punishment in the study area. At bivariate level chi-square $\left(\chi^{2}\right)$ test was applied to determined relationship between (psychological variables) on the phenomena of corporal punishment. The Chi square $\chi^{2}$ was using while adopting the procedure outlined by Mac Call, (1975).

$$
\chi_{\text {obs }}{ }^{2}=\sum_{j=1}^{r} \sum_{k=1}^{c} \frac{\left(\mathbf{O}_{j k}-E_{j k}\right)^{2}}{E_{j k}}
$$

Gamma was used to determine the strength and direction of relationship between independent and dependent variables. Gamma was used by applying the procedure applied by Nachmias and Nachmias (1981) to find association of contingency table.

The formula for Gamma statistic is as following;

$$
\gamma=\frac{N s-N d}{N s+N d}
$$

\section{Results}

Table 1

Parent'sperception on corporal punishment

\begin{tabular}{llccccr}
\hline \multicolumn{1}{c}{ Attributes } & Response & \multicolumn{4}{c}{ Perception on corporal punishment } & \multirow{2}{*}{ Statistics } \\
\cline { 3 - 6 } & & Yes & No & $\begin{array}{c}\text { Don't } \\
\text { know }\end{array}$ & Total & \\
\cline { 3 - 6 } $\begin{array}{l}\text { Corporal punishment } \\
\text { increases aggressiveness }\end{array}$ & Yes & $153(75.7)$ & $13(6.4)$ & $1(0.5)$ & $167(82.7)$ & $X^{2}=131.490$ \\
& No & $1(0.5)$ & $21(10.4)$ & $8(4.0)$ & $30(14.9)$ & $(0.001)$ \\
& Don't Know & $0(0.0)$ & $3(1.5)$ & $2(1.0)$ & $5(2.5)$ & $\gamma=.977$ \\
Corporal punishment & Yes & $153(75.7)$ & $12(5.9)$ & $1(0.5)$ & $166(82.2)$ & $X^{2}=139.434$ \\
Promotes depression & No & $1(0.5)$ & $15(7.4)$ & $4(2.0)$ & $20(9.9)$ & $(0.001)$ \\
& Don't Know & $10(75.7)$ & $10(75.7)$ & $6(75.7)$ & $16(7.9)$ & $\gamma=.972$ \\
Corporal punishment & Yes & $151(74.8)$ & $11(5.4)$ & $1(0.5)$ & $163(80.7)$ & $X^{2}=129.175$ \\
stimulate nervousness & No & $3(1.5)$ & $16(7.9)$ & $7(3.5)$ & $26(12.9)$ & $(0.001)$ \\
& Don't Know & $0(0.0)$ & $10(5.0)$ & $3(1.5)$ & $13(6.4)$ & $\gamma=.954$ \\
Corporal punishment & Yes & $51(25.2)$ & $4(2.0)$ & $0(0.0)$ & $55(27.2)$ & $X^{2}=15.340$ \\
\hline
\end{tabular}

Peshawar Journal of Psychology and Behavioral Sciences, 2015, Vol. 1, No. 2, 137-150 


\begin{tabular}{|c|c|c|c|c|c|c|}
\hline $\begin{array}{l}\text { causing factor of } \\
\text { suicidal feelings }\end{array}$ & $\begin{array}{l}\text { No } \\
\text { Don't Know }\end{array}$ & $\begin{array}{l}79(39.1) \\
24(11.9)\end{array}$ & $\begin{array}{l}25(12.4) \\
8(4.0)\end{array}$ & $\begin{array}{l}6(3.0) \\
5(2.5)\end{array}$ & $\begin{array}{c}110(54.5) \\
37(18.3)\end{array}$ & $\begin{array}{l}(0.004) \\
\gamma=.481\end{array}$ \\
\hline $\begin{array}{l}\text { orporal puni } \\
\text { ings uncerta }\end{array}$ & $\begin{array}{l}\text { Yes } \\
\text { No } \\
\text { Don't Know }\end{array}$ & $\begin{array}{c}153(75.7) \\
0(0.0) \\
1(0.5)\end{array}$ & & & & $\begin{array}{r}X^{2}=131.728 \\
(0.001) \\
\gamma=.963\end{array}$ \\
\hline nt & $\begin{array}{l}\text { Yes } \\
\text { No } \\
\text { Don't Know }\end{array}$ & $\begin{array}{c}153(75.7) \\
1(0.5) \\
0(0.0)\end{array}$ & & $\begin{array}{l}3(1 \\
6(3 \\
2(1\end{array}$ & $\begin{array}{c}176(87.1) \\
17(8.4) \\
9(4.5)\end{array}$ & $\begin{array}{r}X^{2}=94.774 \\
(0.001) \\
\gamma=.944\end{array}$ \\
\hline orpc & $\begin{array}{l}\text { Yes } \\
\text { No } \\
\text { Don't Know }\end{array}$ & $\begin{array}{c}146(72.3) \\
3(1.5) \\
5(2.5)\end{array}$ & $\begin{array}{c}9(4.5) \\
19(9.4) \\
9(4.5)\end{array}$ & & $\begin{array}{c}156(77.2) \\
26(12.9) \\
20(9.9)\end{array}$ & $\begin{array}{r}X^{2}=124.545 \\
(0.000) \\
\gamma=.914\end{array}$ \\
\hline orp & $\begin{array}{l}\text { Yes } \\
\text { No } \\
\text { Don't know }\end{array}$ & $\begin{array}{c}146(72.3) \\
4(2.0) \\
4(2.0)\end{array}$ & $\begin{array}{c}10(5.0) \\
22(10.9) \\
5(2.5)\end{array}$ & & $\begin{array}{c}157(77.7) \\
32(15.8) \\
13(6.4)\end{array}$ & $\begin{array}{r}X^{2}=118.287 \\
(0.000) \\
\gamma=.913\end{array}$ \\
\hline $\begin{array}{l}\text { orporal punishment } \\
\text { cline feelings of } \\
\text { mpathy }\end{array}$ & $\begin{array}{l}\text { No } \\
\text { Don't Know }\end{array}$ & $\begin{array}{l}4(2.0) \\
4(2.0)\end{array}$ & $\begin{array}{l}18(8.9) \\
9(4.5)\end{array}$ & $\begin{array}{l}5(2.5) \\
5(2.5)\end{array}$ & $\begin{array}{c}157(77.7) \\
27(13.4) \\
19(8.9)\end{array}$ & $\begin{array}{r}X^{2}=114.216 \\
(0.001) \\
\gamma=.915\end{array}$ \\
\hline $\begin{array}{l}\text { orporal punishment } \\
\text { otivate sexual feeling } \\
\text { children }\end{array}$ & $\begin{array}{l}\text { Yes } \\
\text { No } \\
\text { Don't Know }\end{array}$ & $\begin{array}{l}43(21.3) \\
63(31.2) \\
48(23.8)\end{array}$ & $\begin{array}{c}3(1.5) \\
19(9.4) \\
15(7.4)\end{array}$ & $\begin{array}{l}0(0.0) \\
5(2.5) \\
6(3.0)\end{array}$ & $\begin{array}{l}4622.8) \\
87(43.1) \\
69(34.2)\end{array}$ & $\begin{array}{r}X^{2}=10.746 \\
\gamma=.667\end{array}$ \\
\hline
\end{tabular}

Note. Number in Table Represent Frequencies and Number in Parenthesis Represent Percentage Proportion of Respondents.

\section{Discussion}

Psychologically, the behavior usually stems out with two dimensions. The first covers the idea, while the later is based on action through generation of idea. Moreover, these ideas and actions are under constant check through societal process of social sanctions containing prescribed and proscribed norms. Corporal punishment is also having psychological impacts on the minds of the people particularly of parent's minds. Following lines indicates about the parents' Psychological perception with reference to corporal punishment.

Table-1 indicated that out of $100 \%, 82.7 \%$ of the respondents opined that corporal punishment increases aggressiveness in children, while $14.9 \%$ negated the former statement and $2.5 \%$ had no idea about it. These findings are supported by (Becker, 1964; and Steinmetz, 1979) that corporal punishment affects children academic achievements, disturbs personality and ultimately results in aggressive behavior, associated with enlargement of the problem of aggressive habits in 
children. Similarly Vygotsky (1978) pointed out that the phenomena of corporal punishment is the outcome of socialization process and is best suited to attribute it to the social learning theory. Because when children experience corporal punishment its outcome is aggressiveness in children.

Similarly, $82.2 \%$ of the respondents believed that corporal punishment promotes depression in children, while $9.9 \%$ negated the former statement and $7.9 \%$ had no idea about it. Results of the previous literature show that corporal punishment would lead to symptoms of depression and associated with pain in children (McLoyd et al, 1994; and Stephen, 1972) as it could have permanent effects on the children personality in future life when they step into parenthood. Heaven and Goldstein (2001) highlighted that the problem of depression is associated with the negligence of children from parent's side and penalizing behavior of discipline particularly in girls who were more subjected to negative outcomes as compared to boys.

Furthermore, $80.7 \%$ of the respondents stated that corporal punishment stimulates nervousness in children, while $12.9 \%$ denied of it and $6.4 \%$ had no information about it. Similar results are also shown by Stephen (1972) that corporal punishment is a multifaceted in terms of its outcomes like it hampers the confidence level, increases tension, boosts rigidity in behavior which in one way or other ends up in nervousness in children and subsequently deteriorating the personality building process.

Also majority i.e. $54.5 \%$ of the respondents had opined that corporal punishment is not causing factor of suicidal feelings, $27.2 \%$ had negated the suicidal feelings as the outcome of corporal punishment, and $18.3 \%$ had no idea regarding it. These findings are strongly in consonance to the study results of Irwin (1997) that corporal punishment injects the false ideas of committing suicide in the mind of children. That is why it should be banned in academic institutions because it emerges out with feelings of fear, hopelessness, irritation and quarrelsome behavior in the young children.

Mostly, i.e. $82.7 \%$ of the respondents had emphasized that corporal punishment brings uncertainty, while $11.4 \%$ had not supported it and $5.9 \%$ had no information about it. Similar findings are being found that uncertainty is a resultant of corporal punishment. Which adds to so 
many other problems like terror, lake of clear stance and vision about its own, live in isolation having introvert personality makeup, having tension about their school performance (Alan, 2005) and distress (Haq, 1998).

Furthermore, $87.1 \%$ of the respondents emphasized that corporal punishment causing fear and terror, while $8.4 \%$ of the respondents rejected the former statement and $4.5 \%$ had no knowledge about it. Similar findings are found from the earlier review that this trend of corporal punishment is mostly followed in developing and under developed countries as Haq (1998) pointed out that in Nepal where teachers most often use excessive corporal punishment as a tool to make their students disciplined which then ends up in causing terror and fear in the minds of children which hampers their academic growth and high ratio of drop out from schools. Alan (2005) also pin point terror and fear in children as the outcome of corporal punishment. Similarly out of $100 \%, 77.2 \%$ of the respondents emphasized that corporal punishment eliminates confidence, while $12.9 \%$ were not agreed and $9.9 \%$ didn't know that whether corporal punishment eliminates confidence or not. Stephen (1972) also agreed upon that lowering confidence in children resulting aspect of corporal punishment, which negatively effects harnessing of academic process amongst children.

Almost, $77.7 \%$ of the respondents had opined that corporal punishment damage the intelligence coefficient (IQ) of children, while $15.8 \%$ didn't show any agreement to it. These results are in line to the study findings of Straus (2009) while noting the findings reference of Dr. Murray Straus where he highlighted that the researchers, don't write that bodily injuries, continued suffering as a result of spanking at time not directly affect the child IQ. Likewise out of $100 \%, 77.7 \%$ of the respondents believed that corporal punishment declines feelings of sympathy, while $13.4 \%$ of the respondents refused from the former statement and $8.9 \%$ emphasized that they had no idea about it. The results of Harvard Mental Health Letter (2002) are in support to these findings as it disclosed the declining sympathetic feelings in children as an outcome of corporal punishment.

In addition, $22.8 \%$ of the respondents emphasized that corporal punishment motivates sexual feeling in children, while majority i.e. $43.1 \%$ of the respondents viewed that corporal punishment doesn't motivates sexual feeling in children and $34.2 \%$ did not provide any 
information about it. Harvard Mental Health Letter (2002) presented the same results and highlighted that corporal punishment also cause hopelessness, departure, nervousness, stress problems in the young children and big children, produced the problem of maltreatment, academic hindrance, which enhance motivational drives.

Human beings had different perception about things and situation. The following lines show people perception about corporal punishment of children. Table-2 provided the information on the relationship between psychological aspects with respondent's perception on corporal punishment. It shows the respondents perception on relationship between corporal punishment and increases aggressiveness. Gamma indicated a highly positive $(\gamma=0.977)$, and significant $(\mathrm{P}<0.05)$ relationship detected between aggressiveness and perception on corporal punishment, which highlighted that people understood that corporal punishment increases aggression. These findings are supported (Becker, 1964; and Steinmetz, 1979) that it affects children academic achievements disturbs personality and ultimately results in aggressive behavior, associated with enlargement of the problem of aggressive habits in children. Vygotsky (1978) pointed out that the phenomena of corporal punishment is the outcome of socialization process and is best suited to attribute it to the social learning theory. Because when children experience corporal punishment its outcome is aggressiveness in children.

Furthermore, the study showed the respondent's perception about relationship between whether corporal punishment promotes depression in children or not? A highly positive $(\gamma=.972)$, relationship indicated by Gamma with a significant $(\mathrm{P}<0.05)$ relationship between depression and perception on corporal punishment, which clearly states that a strong relationship exist between corporal punishment and increase of depression and tension amongst children. Results of the previous literature show that corporal punishment would leads to symptoms of depression and associated with pain in children (McLoyd et al, 1994; and Stephen, 1972) as it could have permanent effects on the children personality in future life when they step into parenthood. Heaven and Goldstein (2001) highlighted that the problem of depression is associated 
with the negligence of children from parent's side and penalizing behavior of discipline particularly in girls who were more subjected to negative outcomes as compared to boys.

The study further revealed the relationship between respondent's perception on corporal punishment and nervousness in children. Gamma $(\gamma=.954)$, showed a highly positive relationship and a significant $(\mathrm{P}<$ $0.05)$ relationship detected between nervousness with knowledge of the respondents perception regarding corporal punishment. Similar results are also shown by Stephen (1972) that corporal punishment respectively, is a multifaceted in terms of its outcomes like it hampers the confidence level, increases tension, boosts rigidity in behavior which in one way or other ends up in nervousness in children and subsequently deteriorating the personality building process.

Also a significant $(p<0.05)$ relationship was found between respondents perception on corporal punishment and suicidal feelings in children. The study further highlighted the relationship between corporal punishment causing factor of suicidal feelings with perception on corporal punishment. Gamma $(\gamma=.481)$, indicated a positive relationship. It could easily be depicted between these relationships that people understood the negative effects of physical punishment as stimulating factor towards suicide feelings. These findings are strongly in consonance to the study results of Irwin (1997) that corporal punishment injects the false ideas of committing suicide in the mind of children. That is why it should be banned in academic institutions because it emerges out with feelings of fear, hopelessness, irritation and quarrelsome behavior in the young children.

The study further explored the relationship between corporal punishment brings uncertainty with children. A significant $(\mathrm{P}<0.05)$ and highly positive $(\gamma)=0.963$ relationship detected between uncertainty and corporal punishment. The positive sign depicts that corporal punishment by teachers, parents etc arose the problems of uncertainty in children. They are then unable to ask questions in classroom, interact with teachers, etc. Similar findings are being found that uncertainty is a resultant of corporal punishment. This adds complexity like terror, lake of clear stance and vision about things around; live in isolation having introvert personality makeup, having tension about their school performance (Alan, 2005; and Haq, 1998). 
It was further explored the corporal punishment creates fear and terror. As indicated by $(\gamma=.944)$, positive relationship with a significant $(\mathrm{P}<0.05)$ relationship. It could be easily unearthed that in educational institutions corporal punishment is practiced as a method to ensure obedience but teachers are unaware of the negative impacts of fear and terror as a resultant factor which hinder their academic achievements. These results are in support to the findings of Haq (1998) who pointed out that in Nepal where teachers most often use of excessive corporal punishment as a tool to make their students disciplined which then ends up in causing terror and fear in the minds of children which hampers their academic growth and high ratio of drop out from schools. Terror and fear in children as the outcome of corporal punishment Alan (2005).

The study further examined the relationship of respondent's perception on corporal punishment and elimination of confidence. Showed a highly positive $(\gamma=0.914)$, relationship and a significant ( $P$ $<0.05)$ relationship detected between the phenomena that corporal punishment eliminates confidence. This in turn deteriorates amongst students the confidence of the children in schools. Teachers physically punish students violently, which hinder the development of the cognitive abilities and confidence building of the children. Stephen (1972) also agreed upon that lower confidence in children is the result of corporal punishment, which further stops the harnessing of academic capabilities and strengths of a child.

The study further highlighted the relationship between respondent's perception on corporal punishment and damage IQ of children which Showed a highly positive $(\gamma=0.913)$ relationship. In addition a significant $(\mathrm{P}<0.05)$ relationship detected between the corporal punishment and damages IQ in children. The study found that corporal punishment directly affects children IQ. Those children who experience corporal punishment would have low IQ in comparison to other children. While highlighting the findings of Dr. Murray Straus (2009) found that spanking has no direct affects on child IQ.

It was again disclosed that corporal punishment decline sympathetic feelings as shown. The relationship between corporal punishment and sympathy with a high positive $(\gamma=0.915)$, and a significant $(\mathrm{P}<0.05)$. It is evident from the outcome of this results that 
personality disorders and decline of sympathy could emerge due to corporal punishment. These results are in support to Harvard Mental Health Letter (2002) where a sound relationship was ascertained between corporal punishment and decline sympathy. A positive and significant $(\mathrm{p}>0.05)$ relationship was found between the perception on corporal punishment and motivation of sexual feelings in children. Harvard Mental Health Letter (2002) presented the same results and highlighted that corporal punishment also cause hopelessness, departure, nervousness, stress problems in the young children and big children, produced the problem of maltreatment, academic hindrance, which enhance motivational drives.

\section{Conclusions and Recommendations}

This study based on parent's perception regarding psychological effects on children by corporal punishment in District Malakand, Khyber Pakhtunkhwa, Pakistan. On the basis of the findings of this study, it is concluded that as psychological aspect show a positive and highly significant relationship between corporal punishment and emotional distress in children, lack of confidence, increase aggressiveness, promotes fear and terror, increase depression, damages IQ of children etc. Regular periodic refreshers courses need to be arranged for teachers to emphasize the worse effects of corporal punishment and certain psychological assessment tests of children at school by social psychologists to mitigate the social and psychological distress, as resulted from use of corporal punishment. Also, it was found that suicide and sexual feelings as the probable outcomes of corporal punishment. Corporal punishment should ban in schools with strict implementations of laws, there must be child psychologist in the school to address the behavioral problems of the students are some of the suggestions on the basis of study findings

\section{Reference}

Alan, M. 2005. Teachers who bully students: patterns and policy implications. Wittenberg University. http://www.stopbullyingnow.com. (Accessed on January 5, 2011). 
Bauer, G.B., R Dubanoski, L.A. Yamanchi. 1990. Corporal punishment in schools. Journal of Adolescent Health published in 1992 Vol, 22. pp. 285, 99.

Becker, W.C. 1964. Consequences of different kinds of parental discipline. In M.L.Hoffman and L.W.Hoffman, (Eds.). Review of Child Development Research (Vol. 1). New York: Russell Sage Foundation. Cited in Human Relations, 1990. 43 (12): 1199p.

Committee on the Rights of the Child. 2006. General Comment No. 8. The Right of the Child to Protection from Corporal Punishment and Other Cruel or Degrading Forms of Punishment. CRC/C/GC/8, Para 3.

District Census Report of Malakand (DCR). 1998. Population census organization statistics division Government of Pakistan Islamabad February 2000. Printed by Population Census Organization, Printing press Islamabad.

Eggleton, T. 2001. Discipline in the School. Education rights for learners, parents and educators, book no 11 Eric Digest. pp.1-13. http://www.erp.org.za/pdf/punish \% 20booklet_WEB.pdf. (Accessed on 10 April, 2011)

Gershoff, E. T. and H. Bitensky. 2007. The Case against Corporal Punishment of Children. Psychology, Public Policy, and Law, 13(4): 231-272.

Haq, M. and K. Haq. 1998. Human Development in South Asia. In Report Corporal Punishment in schools in south Asia, Submitted to the Committee on the Rights of the Child Day of General Discussion on Violence Against Children 28 September 2001. The University Press Limited Dhaka. 6p.

Harvard Mental Health Letter. 2002. "Attention deficit disorder in adults," publisher New Nami child and adolescent action center quarterly publication 2003. 19 (5): 1-3

Heaven, P.C.L. and M. Goldstein. 2001. "Parental influences and mental health among some Australian youth: Cross cultural analysis" Australian Journal of Psychology. 53(3): 170-175. 
Hyman, I.A. and D.C. Perone, 1998. The other side of school violence: Educator policies and practices that may contribute to student misbehavior. Journal of School Psychology.36 (1): 7-27.

Irwin A.H. 1997. What Spanking Does For Kids From, The Case Against Spanking: How to Discipline Your Child Without Hitting. pp. 5862.

Lambert. T. 2010. Flogging has been a common punishment since ancient times. Jesus was flogged before he was crucified.http://www.localhistories.org/ corporal.htm .lp. (Accessed on 20 January, 2011)

Mac, Call and Robert B. 1975. Fundamental statistics for psychology, $2^{\text {nd }}$ edition, Harcourt brace Jovanovich Inc., New York. pp. 303-304.

McLoyd, V.C., T.E. Jayaratne, R. Ceballo, and J. Borquez. (1994). Unemployment and work interruption among African American single mothers: Effects on parenting and adolescent socio emotional functioning. Article first published online: 28 June 2008. Volume 65: 562-589.

Nachmias, David and ChavaNachmias. 1981. Research method in the social sciences. $2^{\text {nd }}$ ed. St. Martin's press. Inc., New York, USA.

Salim, V. 2005. Corporal Punishment and Bullying: The Rights of Learners sponsored. ED.11.Save the children Sweden.2.p.

Steinmetz, S.K. 1979. Disciplinary techniques and their relationship to aggressiveness, dependency, and conscience. W. R. Burr, R. Hill, F. I. Nye, \& I. L. Reiss (Eds.), Contemporary theories about the family:. Research based theories New York: Free Press. Vol.1: 405-438.

Stephen. J. 1972. "Corporal punishment in schools. Ed. Peter Newell. Penguin Education Special. 1p.

Straus. M. 2009. "Children Who Are Spanked Have Lower IQs, New Research Finds" Journal of Aggression Maltreatment \& Trauma, 2009; Science Daily (Sep. 25, 2009). http://www.sciencedaily.com. (Accessed on 17 January, 2011). 
Vygotsky, L.S. 1978. Mind in Society: The Development of Higher Psychological Processes, Harvard University Press, Cambridge, Massachusetts: 114-127. 